\title{
Subthalamic Nucleus Deep Brain Stimulation: Basic Concepts and Novel Perspectives
}

\author{
Clement Hamani, ${ }^{1,2,4}$ Gerson Florence, ${ }^{4}$ Helmut Heinsen, ${ }^{3,9}$ Birgit R. Plantinga, ${ }^{5,6}$ (1) Yasin Temel, ${ }^{6,7}$ \\ Kamil Uludag, ${ }^{8}$ Eduardo Alho, ${ }^{4}$ Manoel J. Teixeira, ${ }^{4}{ }^{-}$Edson Amaro, ${ }^{3}$ and Erich T. Fonoff ${ }^{4,10}$
}

DOI:http://dx.doi.org/10.1523/ENEURO.0140-17.2017

\begin{abstract}
${ }^{1}$ Division of Neurosurgery Sunnybrook Health Sciences Centre, University of Toronto, Toronto, Ontario, Canada, ${ }^{2}$ Division of Neuroimaging, Centre for Addiction and Mental Health, Toronto, Ontario, Canada, ${ }^{3}$ Department of Radiology, University of São Paulo Medical School, São Paulo, Brazil, ${ }^{4}$ Division of Neurosurgery, Department of Neurology, University of São Paulo Medical School, São Paulo, Brazil, ${ }^{5}$ Department of Biomedical Image Analysis, Eindhoven University of Technology, Eindhoven, The Netherlands, ${ }^{6}$ Department of Neurosurgery, Maastricht University Medical Center, Maastricht, The Netherlands, ${ }^{7}$ Donders Institute for Brain, Cognition and Behaviour, Radboud University Medical Center, Nijmegen, The Netherlands, ${ }^{8}$ Department of Cognitive Neuroscience, Maastricht University, Maastricht, The Netherlands, ${ }^{9}$ Department of Psychiatry, Psychosomatics and Psychotherapy, Center of Mental Health, University Clinic of Würzburg, Würzburg, Germany, and ${ }^{10}$ Instituto de Ensino e Pesquisa Hospital Sírio-Libanês, São Paulo, Brazil
\end{abstract}

\begin{abstract}
Over the last decades, extensive basic and clinical knowledge has been acquired on the use of subthalamic nucleus (STN) deep brain stimulation (DBS) for Parkinson's disease (PD). It is now clear that mechanisms involved in the effects of this therapy are far more complex than previously anticipated. At frequencies commonly used in clinical practice, neural elements may be excited or inhibited and novel dynamic states of equilibrium are reached. Electrode contacts used for chronic DBS in PD are placed near the dorsal border of the nucleus, a highly cellular region. DBS may thus exert its effects by modulating these cells, hyperdirect projections from motor cortical areas, afferent and efferent fibers to the motor STN. Advancements in neuroimaging techniques may allow us to identify these structures optimizing surgical targeting. In this review, we provide an update on mechanisms and the neural elements modulated by STN DBS.
\end{abstract}

Key words: subthalamic nucleus; deep brain stimulation; mechanisms; plasticity; anatomy; physiology; neuroimaging

\section{Significance Statement}

Over the last decades, extensive basic and clinical knowledge has been acquired on the use of subthalamic nucleus (STN) deep brain stimulation (DBS) for Parkinson's disease (PD). It is becoming clear that DBS exerts its effects through several mechanisms and influences various neural structures and circuits. In this article, we discuss electrophysiological findings suggesting that stimulation not only modulates activity of neural elements but also leads to novel dynamic states of equilibrium. We also present anatomic data showing that the STN is not a homogeneous structure and review fiber pathways and regions of the nucleus potentially modulated by DBS. Finally, we discuss novel neuroimaging modalities and how these may be used to optimize technical aspects of the surgery.

\section{Introduction}

From its origins to clinical approval, the history of subthalamic nucleus (STN) deep brain stimulation (DBS) for
Parkinson's disease (PD) has been one of extreme success. In the late 1980s, thalamic stimulation was proposed as an alternative to ablative procedures for treating 
patients with tremor (Benabid et al., 1991). In 1-methyl-4phenyl-1,2,3,6-tetrahydropyridine (MPTP)-treated nonhuman primates, both STN lesions (Bergman et al., 1990) and stimulation (Benazzouz et al., 1993) were shown to improve parkinsonian features. Soon after, a series of PD patients was successfully treated with STN DBS (Limousin et al., 1995). To date, over 120,000 patients worldwide have been implanted with DBS systems. In PD, marked improvements have been reported in motor symptoms and levodopa-induced involuntary movements (Deuschl et al., 2006; Weaver et al., 2009).

Aside from impacting patient care, investigational data from preclinical models and surgical candidates have yielded significant advancements in our understanding of the physiology and pathophysiology of the basal ganglia. Despite this fact and the 30 years of experience with DBS, its mechanisms of action are still not fully understood.

In this review, we provide an update on mechanisms and structures modulated by STN stimulation. We discuss the complexity of DBS and the fact that neural elements may be excited or inhibited, reaching novel dynamic states of equilibrium. We also review neuroanatomical substrates modulated by DBS in the region of the STN. Finally, we examine how advancements in neuroimaging techniques may allow us to identify specific STN regions, so that this therapy may be optimized.

\section{Anatomic aspects of the STN and nearby fiber structures}

The STN is a lens-shaped densely populated structure, with extensive membrane apposition between the cell bodies, dendrites, and proximal axonal segments (Chang et al., 1983; Afsharpour, 1985; Hamani et al., 2004). It is predominantly composed of glutamatergic projection neurons with $7.5 \%$ of cells in humans being identified as GABAergic interneurons (Hamani et al., 2004; Lévesque and Parent, 2005). In primates, the STN has been subdivided in a tripartite arrangement based on physiologic characteristics and the distribution of efferent/afferent projections (Alexander et al., 1990; Parent and Hazrati, 1993, 1995a,b; Hamani et al., 2004; Krack et al., 2010; Fig. 1). The limbic STN and part of the associative territory lie in medial-rostral portions of the nucleus. The ventrallateral-rostral portion comprises the remainder of the associative region. The dorsolateral aspects of the rostral STN and the caudal third of the nucleus are associated with motor circuits (Parent and Hazrati, 1995a; Shink et al., 1996; Hamani et al., 2004).

Author contributions: C.H., G.F., H.H., B.R.P., Y.T., K.U., E.Al., M.J.T., E.Am., and E.T.F. wrote the paper.

This work was supported in part with funds from Fundação de Amparo a Pesquisa do Estado de São Paulo - FAPESP and Projeto PROADI SUS - IEP Hospital Sírio-Libanês.

Correspondence should be addressed to Clement Hamani, Division of Neurosurgery, Sunnybrook Health Sciences Centre, 2075 Bayview av S wing S126, Toronto, ON, M4N 3M5, Canada, E mail: clement.hamani@sunnybrook.ca. DOI:http://dx.doi.org/10.1523/ENEURO.0140-17.2017

Copyright (C) 2017 Hamani et al.

This is an open-access article distributed under the terms of the Creative Commons Attribution 4.0 International license, which permits unrestricted use, distribution and reproduction in any medium provided that the original work is properly attributed.

\section{Fiber systems}

One of the characteristics of the STN is that it is enveloped by fibers, including the internal capsule, pallidofugal system, and medial lemniscus.

\section{Pallidofugal systems}

The ansa lenticularis (AL) and fasciulus lenticularis (FL) are largely comprised by globus pallidus internus (GPi)thalamic projections. In primates, the former was thought to originate largely from the lateral GPi (Kuo and Carpenter, 1973; Kim et al., 1976), sweeping around the internal capsule and curving posteriorly to reach the $\mathrm{H}$ field of Forel (Fig. 2). The FL (H2 field of Forel) was believed to arise from the medial GPi (Kuo and Carpenter, 1973; Kim et al., 1976), perforate the internal capsule, and form a bundle ventral to the zona incerta. In contrast to this classical view, however, recent studies suggest that the $\mathrm{AL}$ and $\mathrm{FL}$ should be considered as ventral and dorsal portions of a morphologic continuum that harbors pallidofugal axons arising from all sectors of the GPi (Parent and Parent, 2004). Independent of the origin of pallidothalamic projections, the lenticular fasciculus joins the ansa along with fibers from the superior cerebellar peduncle and brainstem in the $\mathrm{H}$ field of Forel, forming the thalamic fasciculus ( $\mathrm{H} 1$ field of Forel; Hamani et al., 2004; Parent and Parent, 2004). An important aspect to be noticed in nonhuman primates is that a substantial portion of pallidofugal fibers seems to run anterior to the motor STN (Fig. 3).

\section{Afferent and efferent STN projections}

\section{STN-basal ganglia}

Projections from the basal ganglia to the STN derive largely from the globus pallidus externus (GPe) via the subthalamic fasciculus, a fiber bundle that enters/departs the STN from its inferolateral border and crosses the internal capsule. Efferents from the STN to the basal ganglia comprise glutamatergic projections that innervate the globus pallidus, substantia nigra and striatum. Although most STN-nigral projections innervate the pars reticulata (SNr), fibers to the pars compacta (SNc) have received considerable attention as a substrate capable of regulating dopamine release (Smith et al., 1990; Parent and Hazrati, 1995a; Rodriguez et al., 1998). Overall, STNbasal ganglia projections seem to follow the tripartite distribution (Fig. 1; Parent and Hazrati, 1995a; Shink et al., 1996; Hamani et al., 2004; Krack et al., 2010).

\section{STN-cerebral cortex}

The hyperdirect pathway is comprised of motor and premotor cortical fibers that travel though the internal capsule and directly innervate the STN. The former innervates the dorsal STN and arises from the primary motor cortex, supplementary motor area (SMA), pre-SMA, as well as the dorsal and ventral premotor cortices (Nambu et al., 1996; Nambu et al., 1997; Nambu et al., 2000). Ventromedial portions of the nucleus receive afferents from the frontal and supplementary frontal eye fields and are involved in circuits related to eye movements (Matsumura et al., 1992). Prefrontal cortical afferents from 


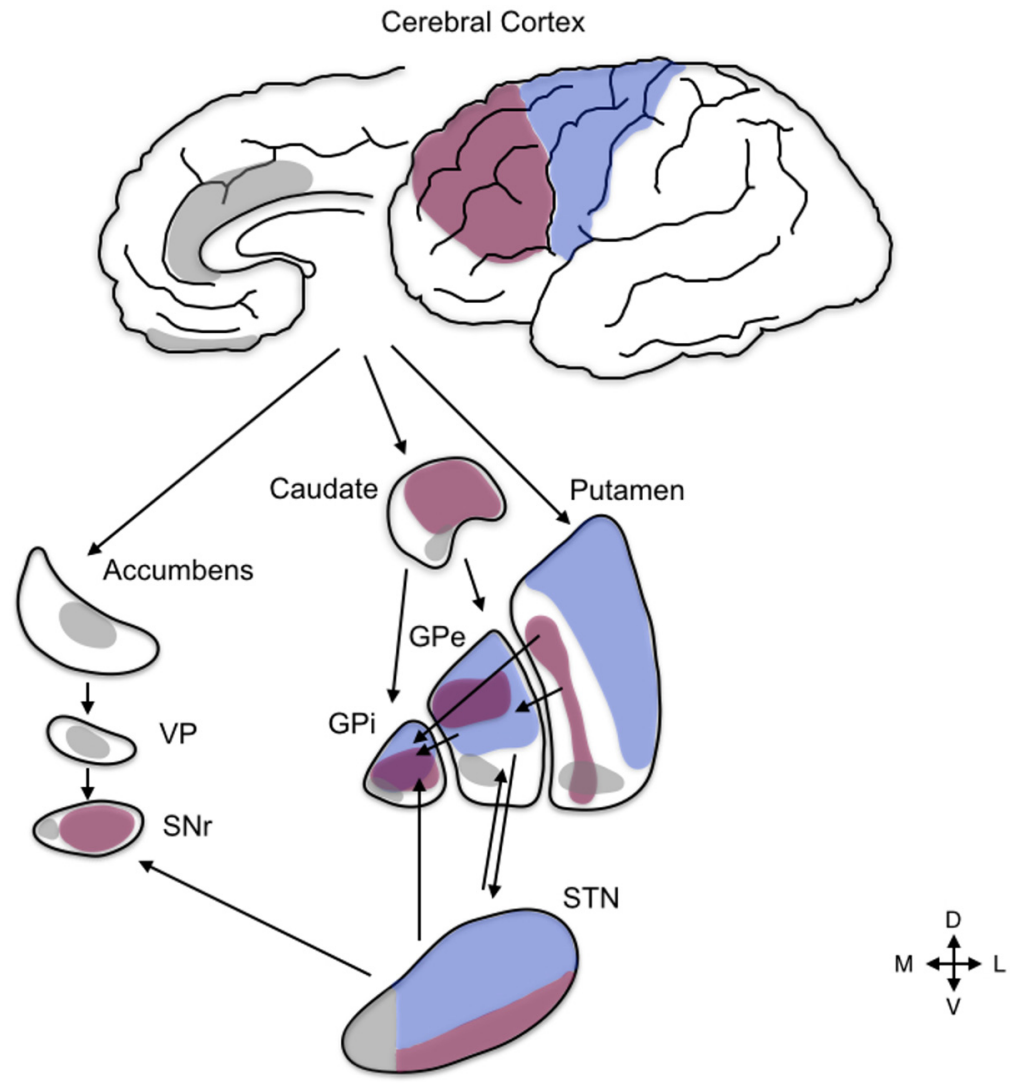

Figure 1. STN and the tripartite model. Intrinsic organization of the STN, basal ganglia structures, and cortical regions according to the tripartite functional subdivision. The motor circuit (blue) includes motor cortical areas (primary motor cortex, supplementary motor cortex, premotor cortex, and portions of the somatosensory dorsal parietal cortex), the dorsolateral portion of the postcommissural putamen, the lateral two-thirds of the globus pallidus (GPe and GPi), and a small portion of the substantia nigra (SNr). In the STN, motor regions comprise dorsal-lateral aspects of the rostrocaudal third of the nucleus (Hamani et al., 2004). Associative circuits (purple) comprise associative cortical regions, most of the caudate nucleus, the putamen rostral to the anterior commissure, the dorsal aspect of the medial third of the globus pallidus (GPe and GPi) and most of the substantia nigra. Associative STN regions may be found in ventral-lateral-rostral portions of the nucleus (Hamani et al., 2004). Limbic circuits (gray) are comprised of limbic cortical areas (e.g., orbitofrontal and the anterior cingulum), the nucleus accumbens and the most rostral portions of the striatum, the subcommissural ventral pallidum (VP), small limbic regions in the ventral portion of the medial third of the globus pallidus (GPe and GPi), the medial tip of the substantia nigra, and the ventral tegmental area. The limbic STN lies in mediorostral portions of the nucleus (Hamani et al., 2004). Arrows represent some of the most important connections between structures. D, dorsal; L, lateral; M, medial; V, ventral. We note that this schematic diagram largely represents structures in two planes with the anteroposterior depiction often lacking. This is the main reason for the superposition of colors representing motor, associative and limbic regions. Parts of this figure were modified and reprinted with permission from Hamani et al. (2004); Krack et al. (2010).

areas the dorsolateral prefrontal cortex and anterior cingulate cortex terminate in ventromedial and medial regions of the STN, respectively (Haynes and Haber, 2013).

\section{Thalamus and brainstem}

The main projections from the thalamus to the STN originate from the parafascicular and centromedian nuclei (Sadikot et al., 1992; Hamani et al., 2004). Brainstem projections arise from various nuclei and involve multiple neurotransmitter systems. These include dopaminergic fibers from the SNc (Lavoie et al., 1989; François et al., 2000; Hamani et al., 2004), cholinergic and noncholinergic projections from the pedunculopontine nucleus and laterodorsal tegmental nuclei (Carpenter et al., 1981; Mesulam et al., 1992; Lavoie and Parent, 1994), noradrenergic fibers from the locus ceruleus (Carpenter et al., 1981), and serotonergic fibers likely from the raphe (Parent et al., 2011).

\section{Physiologic properties of the STN and oscillatory activity}

STN cells in nonhuman primates fire at $18 \pm 25 \mathrm{~Hz}$, mostly in irregular but also regular and bursty patterns (Wichmann et al., 1994a; Hamani et al., 2004). In parkinsonian states, the STN fires more irregularly at higher rates, ultimately disrupting the functioning of downstream basal ganglia structures (Robledo and Féger, 1990; Bergman et al., 1994; Hassani et al., 1996; Hutchison et al., 1998). Also abnormal in PD are cortico-basal ganglia oscillations. STN cells oscillating at frequencies below 10 $\mathrm{Hz}$ are sometimes related to parkinsonian tremor (Levy et al., 2000; Magariños-Ascone et al., 2000). Oscillations 


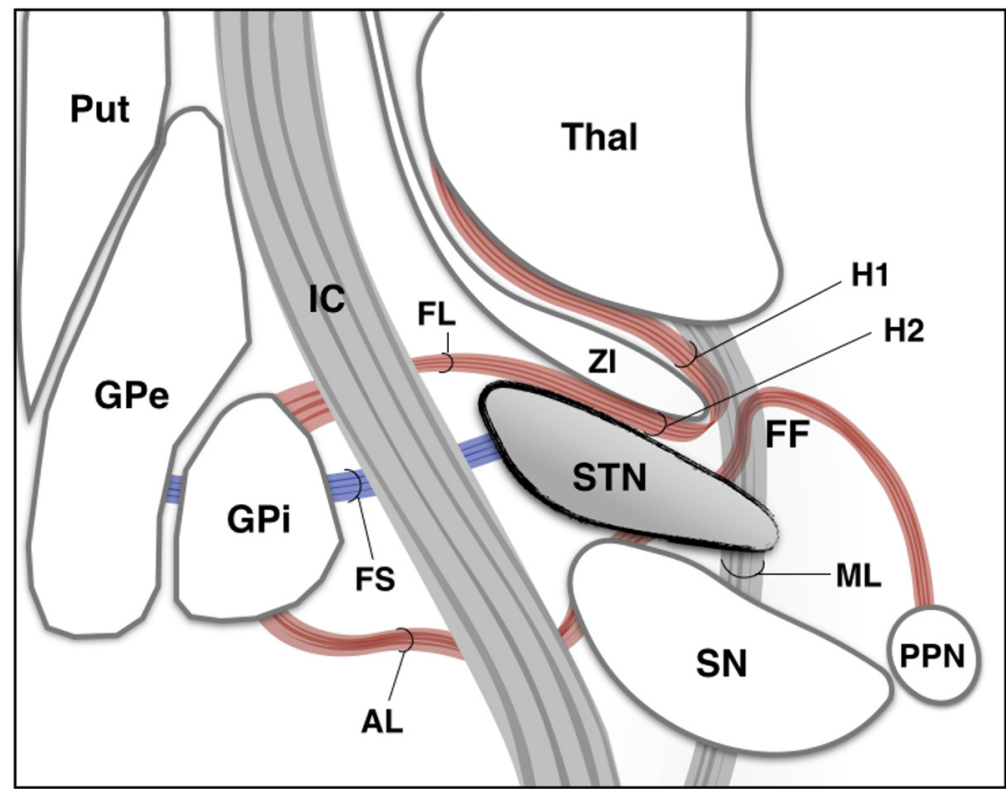

Figure 2. Anatomic aspects of the STN. Principal brain structures surrounding the STN. FF, fields of Forel; FS, subthalamic fascicle; $\mathrm{H} 1, \mathrm{H} 1$ field of Forel (thalamic fasciculus); H2, H2 field of Forel; IC, internal capsule; ML, medial lemniscus; PPN, pedunculopontine nucleus; Put, putamen; SN, substantia nigra; Thal, thalamus; ZI, zona incerta. Part of this figure was modified and reprinted with permission from Hamani et al. (2004).

in the $70-$ to $85-\mathrm{Hz}$ range occur during movement or treatment with dopaminergic agonists (Magill et al., 2001; Levy et al., 2002; Hamani et al., 2004). Oscillations in the beta range $(15-30 \mathrm{~Hz})$ are prominent in sensorimotor regions of the basal ganglia and cortex (Bergman et al., 1994; Brown et al., 2001; Mallet et al., 2008b). These in fact seem to entrain spiking activity in the STN, striatal cholinergic interneurons and basal ganglia downstream structures (Deffains et al., 2016).
In the clinic, while treatment-induced reductions in bradykinesia and rigidity correlate with decreases in beta (Brown et al., 2001; Kühn et al., 2008; Ray et al., 2008; Kühn et al., 2009), STN stimulation at beta frequencies may worsen bradykinesia (Chen et al., 2007; Eusebio et al., 2008). These same results have not been observed in drug-naïve nonhuman primates, which have been shown to develop dystonia and myoclonia but no bradykinesia following STN stimulation (Syed et al., 2012). The
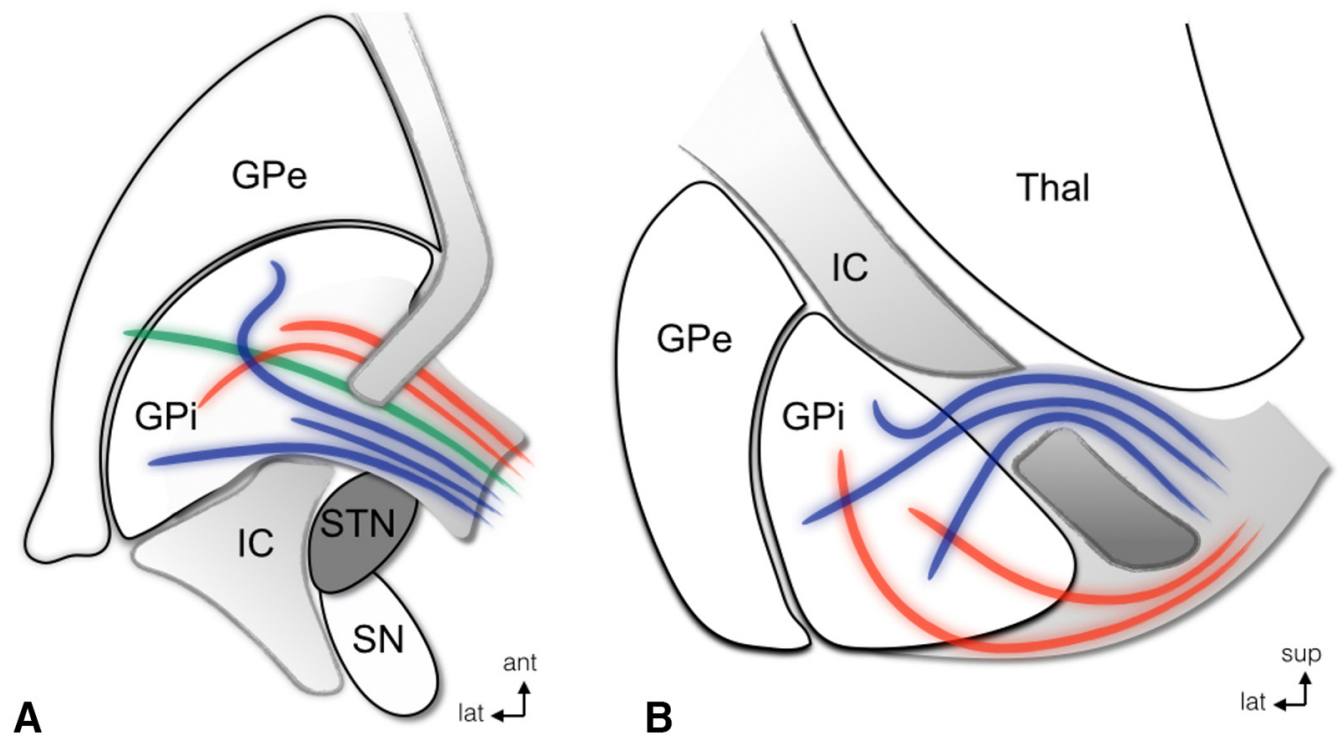

Figure 3. STN and pallidofugal fibers. Axial $(\boldsymbol{A})$ and coronal $(\boldsymbol{B})$ schematic representations of the $A L$ (red) and $L F(H 2 ;$ blue), in relationship to the STN, in nonhuman primates. Note that both the tracts travel dorsal to the most anterior aspect of the STN. $\boldsymbol{A}$, The thalamic fasciculus is represented in green. ant, anterior; lat, lateral; sup, superior. Modified and reprinted with permission from Parent and Parent (2004). 
actual role of beta oscillations on mechanisms of bradykinesia remains disputed.

Also characteristic of PD are altered cross-frequency interactions (CFls; López-Azcárate et al., 2010; Shimamoto et al., 2013; de Hemptinne et al., 2015). These are often appreciated when a more complex analysis of interactions between different frequency bands is conducted (Canolty and Knight, 2010). Similar to beta oscillations, CFls correlate with motor symptoms and may be reversed by the administration of dopaminergic medications (López-Azcárate et al., 2010).

\section{Behavioral effects of STN stimulation}

In rodents, focal injections of GABAergic antagonists into the STN induce postural asymmetry and abnormal movements (Dybdal and Gale, 2000; Périer et al., 2000). Similar to the clinical scenario (Dewey and Jankovic, 1989; Lee and Marsden, 1994), both lesions and the focal inactivation of the STN in nonhuman primates induce ballism, choreic and dyskinetic movements (Hammond et al., 1979; Crossman et al., 1980; Hamada and DeLong, 1992; Beurrier et al., 1997). STN DBS delivered to otherwise naïve nonhuman primates may induce dyskinesias and abnormal movements, particularly when applied at relatively high currents (Beurrier et al., 1997; Hamani et al., 2004). In parkinsonian rodents and primates, STN lesions or high-frequency stimulation (HFS) mitigate motor deficits, bradykinesia, rigidity, and tremor (whenever this is present; Bergman et al., 1990; Aziz et al., 1992; Benazzouz et al., 1993; Wichmann et al., 1994b; Carvalho and Nikkhah, 2001; Darbaky et al., 2003; Hamani et al., 2004).

In addition to motor effects, clinical studies suggest that STN DBS may be associated with impulsivity, cognitive and psychiatric adverse events (Rodriguez-Oroz et al., 2005; Frank et al., 2007; Hälbig et al., 2009; Okun et al., 2009; Weaver et al., 2009; Follett et al., 2010; Bronstein et al., 2011; Rothlind et al., 2015). As patients receiving DBS often have PD and are under pharmacological treatment, the physiologic role of the STN in nonmotor behavior may be better appraised in preclinical models (Hamani and Temel, 2012).

In animals, some of the most commonly investigated nonmotor behaviors are impulsivity, compulsivity, and drug and reward consumption (Hamani and Temel, 2012). Impulsivity can be broadly defined as acting or making decisions without appropriate forethought (Winstanley, 2011). Overall, impulsive behavior encompasses multiple facets, from motor disinhibition to maladaptive decision making, involving motor, attention, and nonplanning aspects (Brunner and Hen, 1997; Evenden, 1999; Winstanley, 2011). Frequently used paradigms to study impulsivity in rodents are those in which individuals need to withhold from making a response (e.g., measurements of reaction time) or have to properly select a response to obtain a reward (e.g., five-choice serial reaction time task; Winstanley, 2011). Commonly observed inappropriate responses during such tasks include prematurely responding to the stimuli or making errors of perseveration. In some of these paradigms, STN lesions or the focal administration of GABAergic agonists in otherwise naïve rats induce impulsive-like behavior (Baunez et al., 1995; Baunez and Robbins, 1997, 1999b). In parkinsonian rodents, STN lesions increase perseverative responses (Baunez and Robbins, 1999a). Compared to lesion studies, the effects of STN DBS are far more controversial. In naïve animals, HFS has been shown not to affect impulse-like behavior (Desbonnet et al., 2004), reduce premature responses (Desbonnet et al., 2004), or even impair performance (e.g., is a visual attention task; Baunez et al., 2007). Similarly, studies in PD animals have shown reversal (Temel et al., 2005; Temel et al., 2006a), no effect (Darbaky et al., 2003), or a transient worsening of associated deficits (Baunez et al., 2007). Reasons for discrepancy across studies remain unclear but may be related to differences in behavioral paradigms, current intensity or the use of unilateral versus bilateral stimulation.

Along with impulsivity, gambling and punding are aspects commonly described as part of the so-called dopamine dysregulation syndrome (DDS; Fenu et al., 2009; O'Sullivan et al., 2009). In the clinic, STN DBS has been used to treat these conditions following the reduction in dopaminergic medication intake (Broen et al., 2011). Preclinical paradigms suited to model some aspects of gambling-type behavior involve the presentation of animals with options associated with variable amounts of reward, from smaller immediate to late but more gratifying compensations (Cocker and Winstanley, 2015). In otherwise naïve rodents, STN-DBS significantly increases the number of premature responses in some of these paradigms (i.e., the selection of immediate disavantageous rewards; Aleksandrova et al., 2013). In contrast, animals bearing STN lesions have a decrease in impulsive decision making and are able to wait for larger delayed rewards (Winstanley et al., 2005; Uslaner and Robinson, 2006).

Another commonly reported side effect of STN DBS is depression (Temel et al., 2006b). Similar to the clinical scenario, rodents treated with STN DBS present depressivelike behavior in different models (Temel et al., 2007; Creed et al., 2013).

In recent years, DBS has been used to treat patients with refractory obsessive-compulsive disorder (OCD; Mallet et al., 2002; Mallet et al., 2008a; Haynes and Mallet, 2010). Preclinical models to mimic this condition are usually characterized by repetitive, excessive and inappropriate behaviors, which may occur either naturally or as a consequence of pharmacological and behavioral manipulations (Joel, 2006; Albelda and Joel, 2012; Hamani and Temel, 2012). A limitation of these paradigms, however, is that they only mimic compulsivity but not obsessions (Albelda and Joel, 2012; Hamani and Temel, 2012). In rodents, STN HFS has been shown to improve perseverative and compulsive-like behaviors (Winter et al., 2008; Klavir et al., 2009). Similarly, nonhuman primates treated with HFS in the limbic portion of the STN had an improvement in compulsive-like features induced the injections of GABAergic antagonists into basal ganglia structures (Baup et al., 2008).

Another interesting aspect of the STN physiology is its role in mechanisms of reward and addiction. In rodents, 
bilateral STN lesions increase motivation to obtain food reward (Baunez et al., 2002; Baunez et al., 2005; Rouaud et al., 2010) while reducing the preference and willingness to work for cocaine (Baunez et al., 2005; Rouaud et al., 2010). When alcohol is considered, STN lesions increase motivation for drug intake in animals considered to be "high drinkers," inducing an opposite effect "low drinker" rats (Lardeux and Baunez, 2008). These results highlight the complexity of physiologic mechanisms of the STN on reward.

\section{Mechanisms of DBS}

Single pulses of cathodic extracellular stimulation depolarize cells, axons, and dendrites. Once action potentials are fired, neurons tend to repolarize, and the normal ionic/neurotransmitter baseline equilibrium is reestablished. These same physiologic responses do not occur when stimulation is delivered at clinical frequencies (i.e., $130-185 \mathrm{~Hz}$ ). For one, only neural appendages fire action potentials in response to HFS. In addition, the continuous delivery of HFS overloads mechanisms responsible for the extracellular removal of certain ions and transmitters (Florence et al., 2016). Ultimately, stimulated regions reach a new dynamic state, characterized by altered ionic currents, nonsynaptic mechanisms, excessive extracellular levels of neurotransmitters/ions (e.g., potassium), and microenvironmental changes that favor the development of plasticity (Hamani and Temel, 2012; Florence et al., 2016).

From a neuronal perspective, a commonly proposed pattern of response following HFS involves the depolarization of axons and functional inhibition of cell bodies (Lozano et al., 2002; Vitek, 2002; Hamani and Temel, 2012; Florence et al., 2016). Although this is well suited to explain some DBS responses, it is rather simplistic. For example, one of the proposed mechanisms for the effects of HFS is the so-called "depolarization block" (Beurrier et al., 2001; Magariños-Ascone et al., 2002; Kringelbach et al., 2007). This has been largely defined as a state in which cells undergo depolarization with an almost complete abolishment of spontaneous action potentials (Beurrier et al., 2001; Magariños-Ascone et al., 2002). The rationale suggesting that depolarization block and a functional target inactivation may play a role in a HFS response stems from the fact that clinical outcome in some DBS applications (e.g., tremor, PD) resembles that observed with lesions. To date, stimulation-induced depolarization blocks have been largely demonstrated in brain slices. In vivo studies conducted in rodents (Tai et al., 2003), nonhuman primates (Meissner et al., 2005), and humans (Filali et al., 2004) have shown striking reductions in the firing of STN cells nearby the electrodes. Yet, the mechanisms responsible for this effect may not only involve a depolarization block but also the excitation of pallidal GABAergic terminals to the STN (Filali et al., 2004).

An aspect not commonly reported, however, is that depolarization blocks are not sustainable events. Over time, cells restore repolarizing mechanisms and become once again capable of firing action potentials until the development of a new depolarization block (Zheng et al.,
2011; Florence et al., 2016). As a result, the same stimulated region may contain cells that are either functionally blocked or firing in tonic or even bursty modes (Kass and Mintz, 2006; Wu and Shuai, 2012). Also, not commonly described is the fact that cells held in a depolarization block are theoretically capable of releasing neurotransmitters. As the membrane potential becomes more positive and the amplitude of action potentials decreases, both intracellular calcium influx and neurotransmitter release are decreased. Depolarized membranes, however, may still release neurotransmitters in smaller nonquanta amounts, even when the cell stops firing. This "synaptic noise" has in fact been shown to modulate postsynaptic currents (Ammari et al., 2011). Depending on the released neurotransmitter, postsynaptic neurons may depolarize or hyperpolarize, becoming more or less responsive to inputs from other presynaptic cells (Fellous et al., 2003; Faisal et al., 2008). Highlighting the importance of this mechanism, STN synaptic noise has been shown to interrupt abnormal oscillatory patterns in parkinsonian animals (Ammari et al., 2011). That said, further evidence is required to confirm the relevance of synaptic noiseassociated neurotransmitter release as a mechanism of DBS.

Another commonly proposed mechanism underlying the effects of HFS is the excitation of fiber pathways (afferent and efferent projections from targeted regions as well as en passant fibers; Kringelbach et al., 2007). This is of importance, as the anterograde and retrograde propagation of action potentials may influence the physiology of brain regions at a distance from the original stimulation site (Windels et al., 2000; Hashimoto et al., 2003; Kringelbach et al., 2007; Temel et al., 2007). Fibers modulated by HFS may be those arriving, departing or passing through (en passant) the target zone. Neurotransmitters released may dictate the effects of DBS at a distance. For example, with a predominance of glutamatergic projection cells DBS in the STN has been shown to increase cell firing in structures innervated by the nucleus (Hashimoto et al., 2003). Microdialysis studies corroborate this assertion, showing glutamate release in output basal ganglia structures (Windels et al., 2000). However, with a complex interplay of modulated afferent and efferent projections, the net effects of DBS are not always predictable. As an example, STN DBS has been shown to significantly reduce neuronal firing in the nigra, particularly when applied at lower amplitudes (Maurice et al., 2003; Tai et al., 2003). This may occur due to an increased release of GABA via the modulation of pallidal activity (Windels et al., 2005). Also contributing to a functional inhibition of circuits, cells at a distance from the DBS target may not recognize stimulation-driven high-frequency rhythms that replace physiologic firing patterns (i.e., "jamming"; Benabid et al., 2002). Finally, we note that, though the main consequence of DBS at $130-185 \mathrm{~Hz}$ is to drive axonal projections, frequencies closer to $200 \mathrm{~Hz}$ may potentially lead to a state of intermittent excitation or even partial blockage of axonal firing (Kilgore and Bhadra, 2004; Florence et al., 2016). 

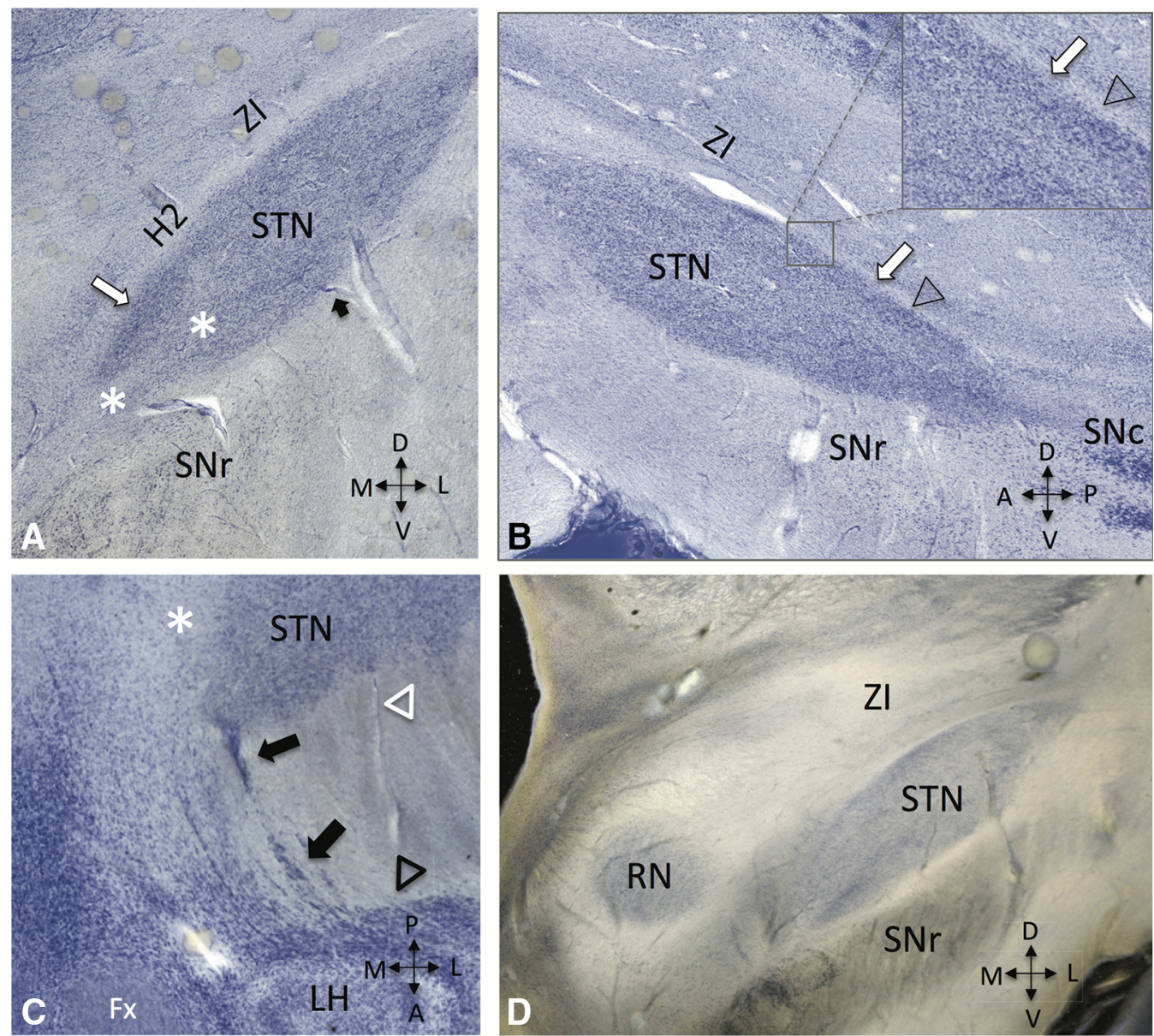

Figure 4. Histologic sections of the subthalamic nucelus (STN) region in individuals with no neurologic disorders stained for gallocyanin. $\boldsymbol{A}$, Note the presence of high-density cellular regions near the borders of the nucleus (white arrow) and fibers inside its core (*). The dark arrow points to a vessel branching in the vicinity of the STN. $\boldsymbol{B}$, Sagittal section (400- $\mu \mathrm{m}$ thickness) showing high-density neuronal clusters (white arrow) and a region largely comprised by capsular fibers (arrowhead) near the dorsal border of the STN. Magnified view is presented in the square above. $\boldsymbol{C}$, Axial (horizontal) section (440- $\mu \mathrm{m}$ thickness) showing the anteromedial aspect of the STN in relation to the lateral hypothalamus $(\mathrm{LH})$ and fornix (Fx). Black arrows denote subthalamic cell strands piercing the internal capsule and forming dissipated accessory cell groups (black open triangle) near the lateral hypothalamus. White open triangles represent the irregular boundary between STN cell clusters and capsular fibers. $\boldsymbol{D}$, Coronal section (440- $\mu \mathrm{m}$ thickness) showing the STN region under dark-field illumination (RN, red nucleus). SNr, substantia nigra reticulata; SNc, substantia nigra compacta; ZI, zona incerta.

Also described following HFS are changes in glial activity, synaptic transmission and the development of various forms of plasticity (Hamani et al., 2012; Cooperrider et al., 2014). In some clinical applications (e.g., dystonia, epilepsy) the effects of DBS are often protracted or build up with time. Although an immediate clinical benefit is often appreciated in PD, when batteries expire patients may not present the same preoperative symptoms or medication requirements, suggesting that plastic events may have reorganized the system.

To date, several studies in PD patients and animal models have shown that STN HFS reduces beta oscillations, coherence between motor cortex and STN activity, and phase amplitude coupling (Wingeier et al., 2006; Eusebio et al., 2008; Kühn et al., 2008; Bronte-Stewart et al., 2009; Giannicola et al., 2010; Tass et al., 2012; de Hemptinne et al., 2015). Some of these signals have been recently proposed to feed closed-loop stimulation sys- tems. Studies in nonhuman primates (Rosin et al., 2011; Johnson et al., 2016) and PD patients (Little et al., 2013) have shown that, compared to regular or intermittent HFS, stimulation delivered following the detection of beta oscillatory bursts or according to the pattern of neuronal firing induce a similar or slightly more pronounced clinical improvement. In a recent report, however, closed-loop STN stimulation delivered to PD primates did not improve bradykinesia during a reaching task (Johnson et al., 2016). This result has been attributed to the fact that beta amplitude declines during motion and suggests that additional work is still needed before closed-loop stimulation may be implemented in the clinic.

\section{Cytoarchitectonic features and elements modulated by DBS}

As most human studies addressing cytoarchitectonic features were conducted with classical staining tech- 
A

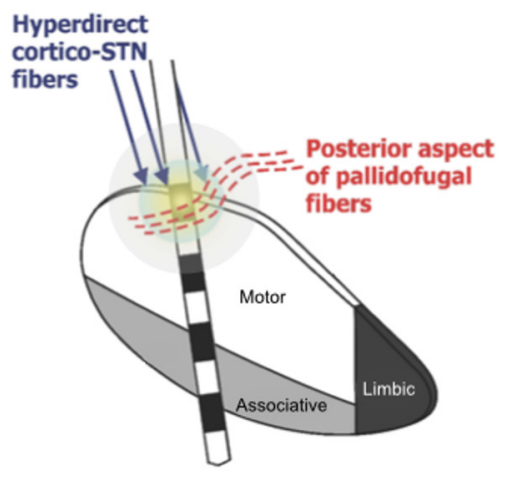

B

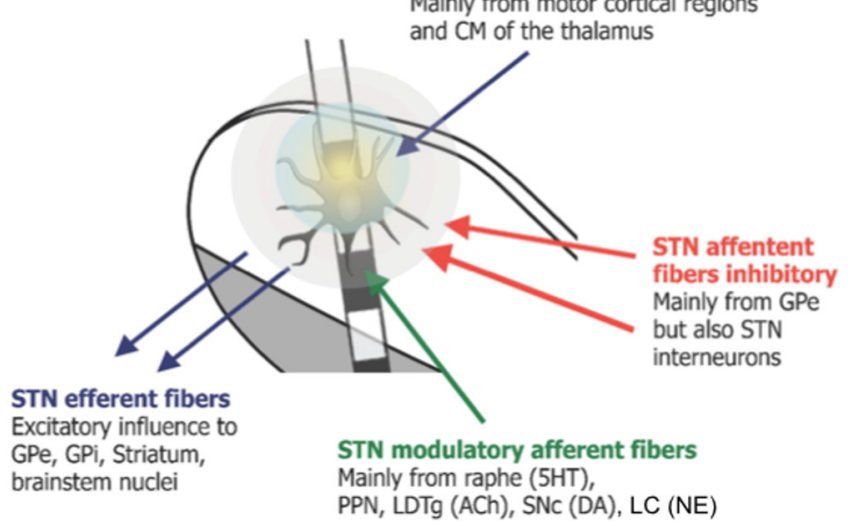

Figure 5. Neural elements modulated by DBS delivered to the dorsal region of the motor subthalamic nucleus (STN) territory. $\boldsymbol{A}$, Schematic representation of the STN showing potential fiber pathways modulated by DBS. Hyperdirect STN projections from motor cortical regions are depicted in blue. Pallidofugal fibers are depicted in red. $\boldsymbol{B}$, Schematic representation of an STN neuron modulated by DBS. STN axons driven by stimulation would excite connected structures. Stimulation of STN afferents would potentially excite these projections, inducing complex effects. STN cells would be excited by stimulation of cortical and thalamic-STN projections (blue) and inhibited by stimulation of globus pallidus projections and appendages from local interneurons (red). Stimulation of brainstem-STN projections would modulate STN neuronal activity via different neurotransmitter systems (green). $5 \mathrm{HT}$, serotonin; ACh, acetylcholine; CM, centromedian nucleus of the thalamus; DA, dopamine; GPe, globus pallidus externus; GPi, globus pallidus internus; LC, locus ceruleus; LDTg, laterodorsal tegmental area; NE, norepinephrine; PPN, pedunculopontine nucleus; SNc, substantia nigra compacta. Part of the figure was reprinted with permission from Hamani et al. (2004).

niques, a few caveats need to be taken into account. First, the STN has an intimate relationship and is partly enwrapped by fibers. Second, its axes are not arranged in parallel to the main axes of the hemispheres. Third, depending on the plane of section, shape and individual orientation, different profiles and grazing artifacts may be observed in Nissl or Golgi-stained sections. Finally, cytoarchitectonic delineations are subject to interindividual variability. When thick gallocyanin stained slices and dark-field illumination sections are examined (Heinsen et al., 2000), a few aspects not previously reported in classical postmortem human studies can be appreciated. (1) Rather than a homogeneous structure, the STN has a looser cellular core and densely packed peripheral regions (Fig. 4). (2) Fiber bundles may be identified near the STN borders as well as in central parts of the nucleus. (3) The medial STN has a fairly irregular outline, with rostromedial strands of cells almost reaching the hypothalamus (Fig. 4).

Electrode contacts used for chronic DBS in PD are often located near the dorsal border of the nucleus (Herzog et al., 2004; Pollo et al., 2007). In addition to being part of the motor territory, this region is characterized by the presence of high-density cellular clusters in postmortem studies. The main fiber pathways entering the motor STN are hyperdirect projections from motor cortical areas, which in fact may be a major substrate modulated by STN DBS (Fig. 5). In agreement with this statement, optogenetic studies have shown that stimulation of hyperdirect pathways may rescue behavioral deficits in parkinsonian rodents (Gradinaru et al., 2009). To date, the modulation of fibers in the fields of Forel, particularly pallidothalamic projections, have been proposed as a potential mechanism for the effects of DBS. Although not many studies have reported anatomic details of these systems in humans, data from nonhuman primates suggest that most of the AL and FL lie slightly anterior to the region where electrodes are often implanted. Other substrates that could be potentially modulated by DBS are axons within the motor STN territory. These may comprise afferents/efferents to and from the motor STN. Stimulation of the former would theoretically excite or inhibit the target zone, depending on the neurotransmitter released (e.g., glutamate from cortical/thalamic afferents, GABA from pallidal afferents, serotonin/dopamine/acetylcholine from brainstem afferents). The excitation of STN glutamatergic efferents would drive activity in structures receiving its projections.

DBS electrodes used to treat OCD are placed in anteromedial regions of the STN (Mallet et al., 2008a). Under these circumstances, cell bodies modulated by stimulation would be those innervating limbic/associative STN territories and nearby hypothalamic regions. Hyperdirect components would be fibers from the dorsolateral prefrontal cortex, orbitofrontal cortex and cingulate gyrus. Stimulated afferents/efferents to and from the STN would be those innervating limbic/associative regions of the basal ganglia, thalamus and brainstem. As PD patients who develop DBS-induced psychiatric side effects often have electrodes implanted medially, the same neural elements could be theoretically involved in mechanisms of these adverse events.

\section{Neuroimaging}

Adequate visualization of the STN greatly depends on MRI protocols. On T2, T2*, and susceptibility weighted images, the nucleus appears as a dark structure. At 1.5T and less so at 3T, MRI identification of the STN may be hindered by limited imaging contrast and the poor identification of the STN/SN border (Fig. 6). Ultrahigh field (7T 


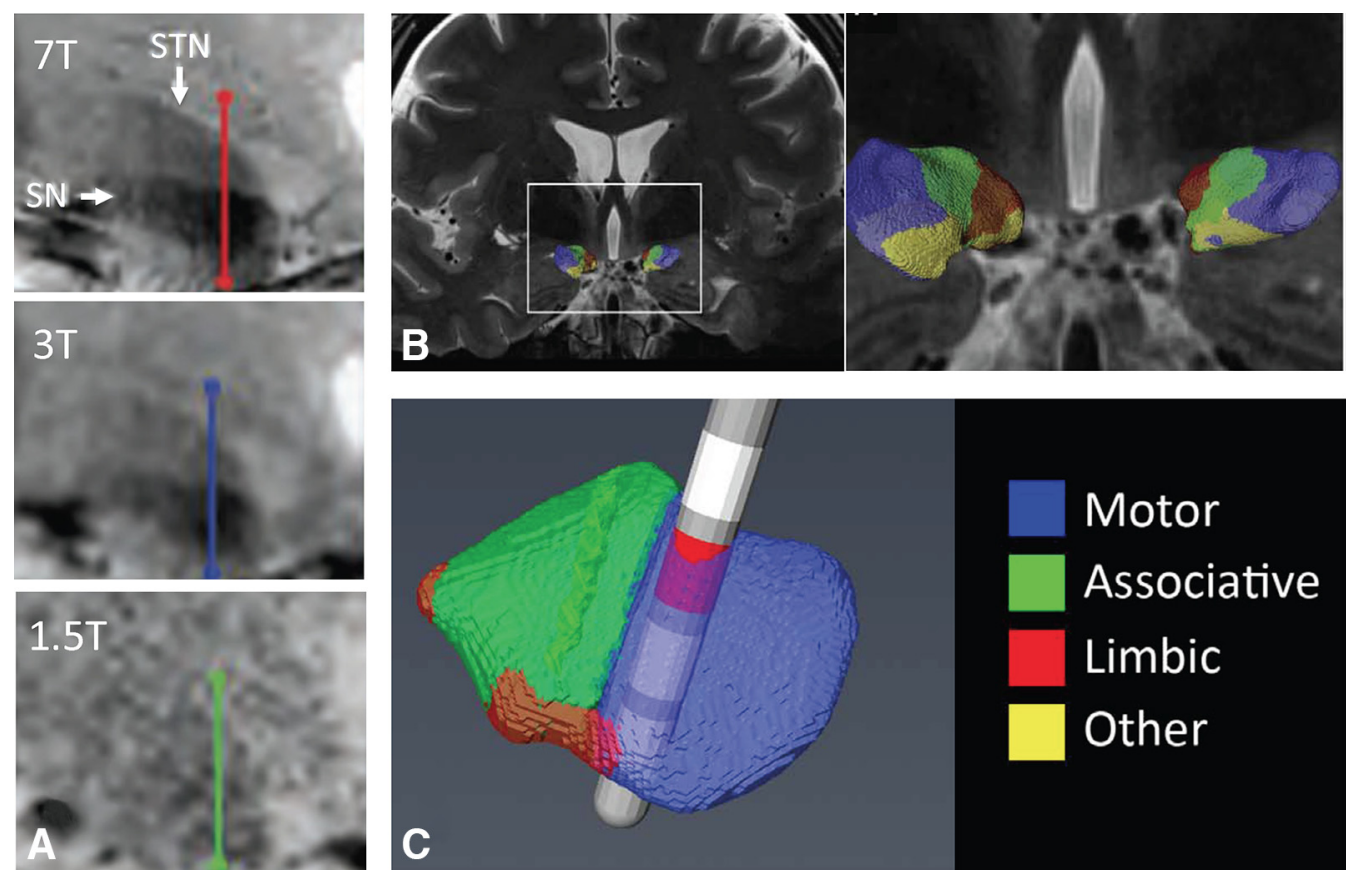

Figure 6. Tractography based subdivision of the STN. $\boldsymbol{A}$, CoronalT2*-weighted images obtained at 7.0T, 3.0T, and 1.5T. $\boldsymbol{B}$, Coronal images showing STN connectivity with limbic (red), associative (green), motor (blue), and remaining (yellow) cortical areas. $\boldsymbol{C}$, Oblique view of the STN with a superposed DBS electrode and an active contact implanted in the motor territory. Reprinted with permission from Cho et al. (2010); Plantinga et al. (2014); Plantinga et al. (2016).

and higher) MRI has the potential to overcome some of these limitations and promises to facilitate patientspecific direct targeting (Plantinga et al., 2014).

As described above, the STN may be subdivided in different subterritories based anatomic connections and physiologic characteristics. The use of diffusion weighted imaging based tractography has been proposed as a potential strategy for classifying deep brain structures into subregions (Behrens et al., 2003). The simplest of these models is diffusion tensor, which can be created with relatively short scan times but fails when there are multiple fiber orientations within one voxel. More advanced models seem to be able to cope with crossing fibers when combined with probabilistic tracking algorithms (Behrens et al., 2007; Tournier et al., 2007). On a group level, these models have been used to subdivide the STN into functional regions in 3T scanners (Lambert et al., 2012). At 7T, the motor region could be successfully discriminated based on structural connectivity (Plantinga et al., 2016; Fig. 6). Although this technique is not without limitations (e.g., false positives and negatives), these results highlight the potential future application of neuroimaging strategies to refine surgical targeting.

\section{Conclusions}

In summary, the mechanisms involved in the effects of DBS seem to be far more complex than previously anticipated. Instead of a simple excitation of fibers and inhibition of cells, neural elements influenced by DBS reach novel dynamic states over time. From an anatomic perspective, human pathologic specimens suggest that the STN has dense cellular aggregates near its borders and a less compact central core, which is infiltrated by fibers.
Discriminating the nature of these fibers and those crossing the dorsal STN border (i.e., where active contacts are implanted) will be crucial for a better appraisal of mechanisms responsible for this therapy.

One of the ultimate goals to be achieved with DBS is to maximize efficacy while minimizing side effects. The former has been attempted by mimicking brain rhythms so that some forms of beta band activity and other pathologic rhythms may be reduced. To date, similar strategies have been effective in preclinical models but still need to be perfected for clinical use. With proven efficacy, a key factor to minimize DBS-induced side effects is to avoid stimulating structures and brain regions involved in adverse events. A major advance toward this objective is the use of directional leads, which may deviate and steer current away from these structures. Also important have been recent advancements in neuroimaging modalities. The use of higher magnetic fields and diffusion/connectivity approaches to identify subregions of the nucleus and specific fiber bundles may advance the way we do surgery by improving targeting precision.

\section{References}

Afsharpour S (1985) Light microscopic analysis of Golgi-impregnated rat subthalamic neurons. J Comp Neur 236:1-13. CrossRef Medline

Albelda N, Joel D (2012) Animal models of obsessive-compulsive disorder: exploring pharmacology and neural substrates. Neurosci Biobehav Rev 36:47-63. CrossRef Medline

Aleksandrova LR, Creed MC, Fletcher PJ, Lobo DS, Hamani C, Nobrega JN (2013) Deep brain stimulation of the subthalamic nucleus increases premature responding in a rat gambling task. Behav Brain Res 245:76-82. CrossRef 
Alexander GE, Crutcher MD, DeLong MR (1990) Basal gangliathalamocortical circuits: parallel substrates for motor, oculomotor, "prefrontal" and "limbic" functions. Prog Brain Res 85:119-146. Medline

Ammari R, Bioulac B, Garcia L, Hammond C (2011) The subthalamic nucleus becomes a generator of bursts in the dopamine-depleted state. Its high frequency stimulation dramatically weakens transmission to the globus pallidus. Front Syst Neurosci 5:43. CrossRef Medline

Aziz TZ, Peggs D, Agarwal E, Sambrook MA, Crossman AR (1992) Subthalamic nucleotomy alleviates parkinsonism in the 1-methyl4-phenyl-1,2,3,6-tetrahydropyridine (MPTP)-exposed primate. $\mathrm{Br}$ $J$ Neurosurg 6:575-582. Medline

Baunez C, Robbins TW (1997) Bilateral lesions of the subthalamic nucleus induce multiple deficits in an attentional task in rats. Eur $\mathrm{J}$ Neurosci 9:2086-2099. CrossRef

Baunez C, Robbins TW (1999a) Effects of dopamine depletion of the dorsal striatum and further interaction with subthalamic nucleus lesions in an attentional task in the rat. Neuroscience 92:13431356.

Baunez C, Robbins TW (1999b) Effects of transient inactivation of the subthalamic nucleus by local muscimol and APV infusions on performance on the five-choice serial reaction time task in rats. Psychopharmacology (Berl) 141:57-65.

Baunez C, Nieoullon A, Amalric M (1995) In a rat model of parkinsonism, lesions of the subthalamic nucleus reverse increases of reaction time but induce a dramatic premature responding deficit. J Neurosci 15:6531-6541.

Baunez C, Amalric M, Robbins TW (2002) Enhanced food-related motivation after bilateral lesions of the subthalamic nucleus. J Neurosci 22:562-568. Medline

Baunez C, Dias C, Cador M, Amalric M (2005) The subthalamic nucleus exerts opposite control on cocaine and 'natural' rewards. Nat Neurosci 8:484-489. CrossRef Medline

Baunez C, Christakou A, Chudasama Y, Forni C, Robbins TW (2007) Bilateral high-frequency stimulation of the subthalamic nucleus on attentional performance: transient deleterious effects and enhanced motivation in both intact and parkinsonian rats. Eur $\mathrm{J}$ Neurosci 25:1187-1194. CrossRef Medline

Baup N, Grabli D, Karachi C, Mounayar S, François C, Yelnik J, Féger $J$, Tremblay L (2008) High-frequency stimulation of the anterior subthalamic nucleus reduces stereotyped behaviors in primates. $J$ Neurosci 28:8785-8788. CrossRef Medline

Behrens TE, Johansen-Berg H, Woolrich MW, Smith SM, WheelerKingshott CA, Boulby PA, Barker GJ, Sillery EL, Sheehan K, Ciccarelli O, Thompson AJ, Brady JM, Matthews PM (2003) Noninvasive mapping of connections between human thalamus and cortex using diffusion imaging. Nat Neurosci 6:750-757. CrossRef Medline

Behrens TE, Berg HJ, Jbabdi S, Rushworth MF, Woolrich MW (2007) Probabilistic diffusion tractography with multiple fibre orientations: what can we gain? Neuroimage 34:144-155. CrossRef Medline

Benabid AL, Pollak P, Gervason C, Hoffmann D, Gao DM, Hommel M, Perret JE, de Rougemont J (1991) Long-term suppression of tremor by chronic stimulation of the ventral intermediate thalamic nucleus. Lancet 337:403-406. Medline

Benabid AL, Benazzous A, Pollak P (2002) Mechanisms of deep brain stimulation. Mov Disord 17 [Suppl3]:S73-S74. CrossRef

Benazzouz A, Gross C, Féger J, Boraud T, Bioulac B (1993) Reversal of rigidity and improvement in motor performance by subthalamic high-frequency stimulation in MPTP-treated monkeys. Eur J Neurosci 5:382-389. Medline

Bergman H, Wichmann T, DeLong MR (1990) Reversal of experimental parkinsonism by lesions of the subthalamic nucleus. Science 249:1436-1438. Medline

Bergman H, Wichmann T, Karmon B, DeLong MR (1994) The primate subthalamic nucleus. II. Neuronal activity in the MPTP model of parkinsonism. J Neurophysiol 72:507-520. Medline
Beurrier C, Bezard E, Bioulac B, Gross C (1997) Subthalamic stimulation elicits hemiballismus in normal monkey. Neuroreport 8:1625-1629. Medline

Beurrier C, Bioulac B, Audin J, Hammond C (2001) High-frequency stimulation produces a transient blockade of voltage-gated currents in subthalamic neurons. J Neurophysiol 85:1351-1356. Medline

Broen M, Duits A, Visser-Vandewalle V, Temel Y, Winogrodzka A (2011) Impulse control and related disorders in Parkinson's disease patients treated with bilateral subthalamic nucleus stimulation: a review. Parkinsonism Relat Disord 17:413-417. CrossRef Medline

Bronstein JM, Tagliati M, Alterman RL, Lozano AM, Volkmann J, Stefani A, Horak FB, Okun MS, Foote KD, Krack P, Pahwa R, Henderson JM, Hariz MI, Bakay RA, Rezai A, Marks WJ Jr, Moro E, Vitek JL, Weaver FM, Gross RE, et al. (2011) Deep brain stimulation for Parkinson disease: an expert consensus and review of key issues. Arch Neurol 68:165. CrossRef Medline

Bronte-Stewart H, Barberini C, Koop MM, Hill BC, Henderson JM, Wingeier B (2009) The STN beta-band profile in Parkinson's disease is stationary and shows prolonged attenuation after deep brain stimulation. Exp Neurol 215:20-28. CrossRef Medline

Brown P, Oliviero A, Mazzone P, Insola A, Tonali P, Di Lazzaro V (2001) Dopamine dependency of oscillations between subthalamic nucleus and pallidum in Parkinson's disease. J Neurosci 21:10331038. Medline

Brunner D, Hen R (1997) Insights into the neurobiology of impulsive behavior from serotonin receptor knockout mice. Ann NY Acad Sci 836:81-105. Medline

Canolty RT, Knight RT (2010) The functional role of cross-frequency coupling. Trends Cogn Sci 14:506-515. CrossRef Medline

Carpenter MB, Carleton SC, Keller JT, Conte P (1981) Connections of the subthalamic nucleus in the monkey. Brain Res 224:1-29. Medline

Carvalho GA, Nikkhah G (2001) Subthalamic nucleus lesions are neuroprotective against terminal 6-OHDA-induced striatal lesions and restore postural balancing reactions. Exp Neurol 171:405417. CrossRef Medline

Chang HT, Kita H, Kitai ST (1983) The fine structure of the rat subthalamic nucleus: an electron microscopic study. J Comp Neur 221:113-123. CrossRef Medline

Chen CC, Litvak V, Gilbertson T, Kühn A, Lu CS, Lee ST, Tsai CH, Tisch S, Limousin P, Hariz M, Brown P (2007) Excessive synchronization of basal ganglia neurons at $20 \mathrm{~Hz}$ slows movement in Parkinson's disease. Exp Neurol 205:214-221. CrossRef Medline Cho ZH, Min HK, Oh SH, Han JY, Park CW, Chi JG, Kim YB, Paek SH, Lozano AM, Lee KH (2010) Direct visualization of deep brain stimulation targets in Parkinson disease with the use of 7-tesla magnetic resonance imaging. J Neurosurg 113:639-647. CrossRef

Cocker PJ, Winstanley CA (2015) Irrational beliefs, biases and gambling: exploring the role of animal models in elucidating vulnerabilities for the development of pathological gambling. Behav Brain Res 279:259-273. CrossRef Medline

Cooperrider J, Furmaga H, Plow E, Park HJ, Chen Z, Kidd G, Baker KB, Gale JT, Machado AG (2014) Chronic deep cerebellar stimulation promotes long-term potentiation, microstructural plasticity, and reorganization of perilesional cortical representation in a rodent model. J Neurosci 34:9040-9050. CrossRef

Creed MC, Hamani C, Nobrega JN (2013) Effects of repeated deep brain stimulation on depressive- and anxiety-like behavior in rats: comparing entopeduncular and subthalamic nuclei. Brain Stimul 6:506-514. CrossRef Medline

Crossman AR, Sambrook MA, Jackson A (1980) Experimental hemiballismus in the baboon produced by injection of a gammaaminobutyric acid antagonist into the basal ganglia. Neurosci Lett 20:369-372. Medline

Darbaky Y, Forni C, Amalric M, Baunez C (2003) High frequency stimulation of the subthalamic nucleus has beneficial antiparkin- 
sonian effects on motor functions in rats, but less efficiency in a choice reaction time task. Eur J Neurosci 18:951-956. CrossRef

de Hemptinne C, Swann NC, Ostrem JL, Ryapolova-Webb ES, San Luciano M, Galifianakis NB, Starr PA (2015) Therapeutic deep brain stimulation reduces cortical phase-amplitude coupling in Parkinson's disease. Nat Neurosci 18:779-786. CrossRef Medline

Deffains M, Iskhakova L, Katabi S, Haber SN, Israel Z, Bergman H (2016) Subthalamic, not striatal, activity correlates with basal ganglia downstream activity in normal and parkinsonian monkeys. Elife 5. CrossRef

Desbonnet L, Temel Y, Visser-Vandewalle V, Blokland A, Hornikx V, Steinbusch HW (2004) Premature responding following bilateral stimulation of the rat subthalamic nucleus is amplitude and frequency dependent. Brain Res 1008:198-204. CrossRef Medline

Deuschl G, Schade-Brittinger C, Krack P, Volkmann J, Schäfer H, Bötzel K, Daniels C, Deutschländer A, Dillmann U, Eisner W, Gruber D, Hamel W, Herzog J, Hilker R, Klebe S, Kloss M, Koy J, Krause M, Kupsch A, Lorenz D, et al. (2006) A randomized trial of deep-brain stimulation for Parkinson's disease. N Engl J Med 355:896-908. CrossRef Medline

Dewey RB Jr, Jankovic J (1989) Hemiballism-hemichorea. Clinical and pharmacologic findings in 21 patients. Arch Neurol 46:862867. Medline

Dybdal D, Gale K (2000) Postural and anticonvulsant effects of inhibition of the rat subthalamic nucleus. J Neurosci 20:67286733. Medline

Eusebio A, Chen CC, Lu CS, Lee ST, Tsai CH, Limousin P, Hariz M, Brown P (2008) Effects of low-frequency stimulation of the subthalamic nucleus on movement in Parkinson's disease. Exp Neurol 209:125-130. CrossRef Medline

Evenden J (1999) Impulsivity: a discussion of clinical and experimental findings. J Psychopharmacol 13:180-192. CrossRef Medline

Faisal AA, Selen LP, Wolpert DM (2008) Noise in the nervous system. Nat Rev Neurosci 9:292-303. CrossRef Medline

Fellous JM, Rudolph M, Destexhe A, Sejnowski TJ (2003) Synaptic background noise controls the input/output characteristics of single cells in an in vitro model of in vivo activity. Neuroscience 122:811-829. CrossRef

Fenu S, Wardas J, Morelli M (2009) Impulse control disorders and dopamine dysregulation syndrome associated with dopamine agonist therapy in Parkinson's disease. Behav Pharmacol 20:363379. CrossRef Medline

Filali M, Hutchison WD, Palter VN, Lozano AM, Dostrovsky JO (2004) Stimulation-induced inhibition of neuronal firing in human subthalamic nucleus. Exp Brain Res 156:274-281. CrossRef Medline

Florence G, Sameshima K, Fonoff ET, Hamani C (2016) Deep brain stimulation: more complex than the inhibition of cells and excitation of fibers. Neuroscientist 22:332-345. CrossRef

Follett KA, Weaver FM, Stern M, Hur K, Harris CL, Luo P, Marks WJ Jr, Rothlind J, Sagher O, Moy C, Pahwa R, Burchiel K, Hogarth P, Lai EC, Duda JE, Holloway K, Samii A, Horn S, Bronstein JM, Stoner G, et al. (2010) Pallidal versus subthalamic deep-brain stimulation for Parkinson's disease. N Engl J Med 362:2077-2091. CrossRef Medline

François C, Savy C, Jan C, Tande D, Hirsch EC, Yelnik J (2000) Dopaminergic innervation of the subthalamic nucleus in the normal state, in MPTP-treated monkeys, and in Parkinson's disease patients. J Comp Neur 425:121-129. Medline

Frank MJ, Samanta J, Moustafa AA, Sherman SJ (2007) Hold your horses: impulsivity, deep brain stimulation, and medication in parkinsonism. Science 318:1309-1312. CrossRef Medline

Giannicola G, Marceglia S, Rossi L, Mrakic-Sposta S, Rampini P, Tamma F, Cogiamanian F, Barbieri S, Priori A (2010) The effects of levodopa and ongoing deep brain stimulation on subthalamic beta oscillations in Parkinson's disease. Exp Neurol 226:120-127. CrossRef Medline

Gradinaru V, Mogri M, Thompson KR, Henderson JM, Deisseroth K (2009) Optical deconstruction of parkinsonian neural circuitry. Science 324:354-359. CrossRef Medline
Hälbig TD, Tse W, Frisina PG, Baker BR, Hollander E, Shapiro H, Tagliati M, Koller WC, Olanow CW (2009) Subthalamic deep brain stimulation and impulse control in Parkinson's disease. Eur $\mathrm{J}$ Neurol 16:493-497. CrossRef Medline

Hamada I, DeLong MR (1992) Excitotoxic acid lesions of the primate subthalamic nucleus result in transient dyskinesias of the contralateral limbs. J Neurophysiol 68:1850-1858. Medline

Hamani C, Temel Y (2012) Deep brain stimulation for psychiatric disease: contributions and validity of animal models. Sci Transl Med 4:142rv8. CrossRef

Hamani C, Saint-Cyr JA, Fraser J, Kaplitt M, Lozano AM (2004) The subthalamic nucleus in the context of movement disorders. Brain 127:4-20. CrossRef Medline

Hamani C, Machado DC, Hipólide DC, Dubiela FP, Suchecki D, Macedo CE, Tescarollo F, Martins U, Covolan L, Nobrega JN (2012) Deep brain stimulation reverses anhedonic-like behavior in a chronic model of depression: role of serotonin and brain derived neurotrophic factor. Biol Psychiatry 71:30-35. CrossRef

Hammond C, Feger J, Bioulac B, Souteyrand JP (1979) Experimental hemiballism in the monkey produced by unilateral kainic acid lesion in corpus Luysii. Brain Res 171:577-580. Medline

Hashimoto T, Elder CM, Okun MS, Patrick SK, Vitek JL (2003) Stimulation of the subthalamic nucleus changes the firing pattern of pallidal neurons. J Neurosci 23:1916-1923. Medline

Hassani OK, Mouroux M, Féger J (1996) Increased subthalamic neuronal activity after nigral dopaminergic lesion independent of disinhibition via the globus pallidus. Neuroscience 72:105-115. Medline

Haynes WI, Mallet L (2010) High-frequency stimulation of deep brain structures in obsessive-compulsive disorder: the search for a valid circuit. Eur J Neurosci 32:1118-1127. CrossRef Medline

Haynes WI, Haber SN (2013) The organization of prefrontalsubthalamic inputs in primates provides an anatomical substrate for both functional specificity and integration: implications for Basal Ganglia models and deep brain stimulation. J Neurosci 33:4804-4814. CrossRef Medline

Heinsen H, Arzberger T, Schmitz C (2000) Celloidin mounting (embedding without infiltration) - a new, simple and reliable method for producing serial sections of high thickness through complete human brains and its application to stereological and immunohistochemical investigations. J Chem Neuroanat 20:49-59. Medline

Herzog J, Fietzek U, Hamel W, Morsnowski A, Steigerwald F, Schrader B, Weinert D, Pfister G, Müller D, Mehdorn HM, Deuschl G, Volkmann J (2004) Most effective stimulation site in subthalamic deep brain stimulation for Parkinson's disease. Mov Disord 19:1050-1054. CrossRef

Hutchison WD, Allan RJ, Opitz H, Levy R, Dostrovsky JO, Lang AE, Lozano AM (1998) Neurophysiological identification of the subthalamic nucleus in surgery for Parkinson's disease. Ann Neurol 44:622-628. CrossRef

Joel D (2006) Current animal models of obsessive compulsive disorder: a critical review. Prog Neuropsychopharmacol Biol Psychiatry 30:374-388. CrossRef Medline

Johnson LA, Nebeck SD, Muralidharan A, Johnson MD, Baker KB, Vitek JL (2016) Closed-loop deep brain stimulation effects on Parkinsonian motor symptoms in a non-human primate - is beta enough? Brain Stimul 9:892-896. CrossRef

Kass JI, Mintz IM (2006) Silent plateau potentials, rhythmic bursts, and pacemaker firing: three patterns of activity that coexist in quadristable subthalamic neurons. Proc Natl Acad Sci USA 103: 183-188. CrossRef Medline

Kilgore KL, Bhadra N (2004) Nerve conduction block utilising highfrequency alternating current. Med Biol Eng Comput 42:394-406. Medline

Kim R, Nakano K, Jayaraman A, Carpenter MB (1976) Projections of the globus pallidus and adjacent structures: an autoradiographic study in the monkey. J Comp Neur 169:263-290. CrossRef Medline

Klavir O, Flash S, Winter C, Joel D (2009) High frequency stimulation and pharmacological inactivation of the subthalamic nucleus re- 
duces 'compulsive' lever-pressing in rats. Exp Neurol 215:101109. CrossRef Medline

Krack P, Hariz MI, Baunez C, Guridi J, Obeso JA (2010) Deep brain stimulation: from neurology to psychiatry? Trends Neurosci 33: 474-484. CrossRef Medline

Kringelbach ML, Jenkinson N, Owen SL, Aziz TZ (2007) Translational principles of deep brain stimulation. Nat Rev Neurosci 8:623-635. CrossRef Medline

Kühn AA, Kempf F, Büucke C, Gaynor Doyle L, Martinez-Torres I, Pogosyan A, Trottenberg T, Kupsch A, Schneider GH, Hariz MI, Vandenberghe W, Nuttin B, Brown P (2008) High-frequency stimulation of the subthalamic nucleus suppresses oscillatory beta activity in patients with Parkinson's disease in parallel with improvement in motor performance. J Neurosci 28:6165-6173. CrossRef Medline

Kühn AA, Tsui A, Aziz T, Ray N, Brücke C, Kupsch A, Schneider GH, Brown P (2009) Pathological synchronisation in the subthalamic nucleus of patients with Parkinson's disease relates to both bradykinesia and rigidity. Exp Neurol 215:380-387. CrossRef Medline

Kuo JS, Carpenter MB (1973) Organization of pallidothalamic projections in the rhesus monkey. J Comp Neur 151:201-236. CrossRef Medline

Lambert C, Zrinzo L, Nagy Z, Lutti A, Hariz M, Foltynie T, Draganski B, Ashburner J, Frackowiak R (2012) Confirmation of functional zones within the human subthalamic nucleus: patterns of connectivity and sub-parcellation using diffusion weighted imaging. Neuroimage 60:83-94. CrossRef Medline

Lardeux S, Baunez C (2008) Alcohol preference influences the subthalamic nucleus control on motivation for alcohol in rats. Neuropsychopharmacology 33:634-642. CrossRef Medline

Lavoie B, Parent A (1994) Pedunculopontine nucleus in the squirrel monkey: projections to the basal ganglia as revealed by anterograde tract-tracing methods. J Comp Neur 344:210-231. CrossRef Medline

Lavoie B, Smith Y, Parent A (1989) Dopaminergic innervation of the basal ganglia in the squirrel monkey as revealed by tyrosine hydroxylase immunohistochemistry. J Comp Neur 289:36-52. CrossRef Medline

Lee MS, Marsden CD (1994) Movement disorders following lesions of the thalamus or subthalamic region. Mov Disord 9:493-507. CrossRef Medline

Lévesque JC, Parent A (2005) GABAergic interneurons in human subthalamic nucleus. Mov Disord 20:574-584. CrossRef Medline

Levy R, Hutchison WD, Lozano AM, Dostrovsky JO (2000) Highfrequency synchronization of neuronal activity in the subthalamic nucleus of parkinsonian patients with limb tremor. J Neurosci 20:7766-7775. Medline

Levy R, Ashby P, Hutchison WD, Lang AE, Lozano AM, Dostrovsky JO (2002) Dependence of subthalamic nucleus oscillations on movement and dopamine in Parkinson's disease. Brain 125:11961209. Medline

Limousin P, Pollak P, Benazzouz A, Hoffmann D, Le Bas JF, Broussolle E, Perret JE, Benabid AL (1995) Effect of parkinsonian signs and symptoms of bilateral subthalamic nucleus stimulation. Lancet 345:91-95. Medline

Little S, Pogosyan A, Neal S, Zavala B, Zrinzo L, Hariz M, Foltynie T, Limousin P, Ashkan K, FitzGerald J, Green AL, Aziz TZ, Brown P (2013) Adaptive deep brain stimulation in advanced Parkinson disease. Ann Neurol 74:449-457. CrossRef Medline

López-Azcárate J, Tainta $M$, Rodríguez-Oroz MC, Valencia $M$, González R, Guridi J, Iriarte J, Obeso JA, Artieda J, Alegre M (2010) Coupling between beta and high-frequency activity in the human subthalamic nucleus may be a pathophysiological mechanism in Parkinson's disease. J Neurosci 30:6667-6677. CrossRef Medline

Lozano AM, Dostrovsky J, Chen R, Ashby P (2002) Deep brain stimulation for Parkinson's disease: disrupting the disruption. Lancet Neurol 1:225-231. Medline

Magariños-Ascone C, Pazo JH, Macadar O, Buño W (2002) Highfrequency stimulation of the subthalamic nucleus silences subtha- lamic neurons: a possible cellular mechanism in Parkinson's disease. Neuroscience 115:1109-1117. Medline

Magariños-Ascone CM, Figueiras-Mendez R, Riva-Meana C, Córdoba-Fernández A (2000) Subthalamic neuron activity related to tremor and movement in Parkinson's disease. Eur J Neurosci 12:2597-2607. Medline

Magill PJ, Bolam JP, Bevan MD (2001) Dopamine regulates the impact of the cerebral cortex on the subthalamic nucleus-globus pallidus network. Neuroscience 106:313-330. Medline

Mallet L, Mesnage V, Houeto JL, Pelissolo A, Yelnik J, Behar C, Gargiulo M, Welter ML, Bonnet AM, Pillon B, Cornu P, Dormont D, Pidoux B, Allilaire JF, Agid Y (2002) Compulsions, Parkinson's disease, and stimulation. Lancet 360:1302-1304. CrossRef Medline

Mallet L, Polosan M, Jaafari N, Baup N, Welter ML, Fontaine D, du Montcel ST, Yelnik J, Chéreau I, Arbus C, Raoul S, Aouizerate B, Damier P, Chabardès S, Czernecki V, Ardouin C, Krebs MO, Bardinet E, Chaynes P, Burbaud P, et al. (2008a) Subthalamic nucleus stimulation in severe obsessive-compulsive disorder. $\mathrm{N}$ Engl J Med 359:2121-2134. CrossRef Medline

Mallet N, Pogosyan A, Sharott A, Csicsvari J, Bolam JP, Brown P, Magill PJ (2008b) Disrupted dopamine transmission and the emergence of exaggerated beta oscillations in subthalamic nucleus and cerebral cortex. J Neurosci 28:4795-4806.

Matsumura M, Kojima J, Gardiner TW, Hikosaka O (1992) Visual and oculomotor functions of monkey subthalamic nucleus. J Neurophysiol 67:1615-1632. Medline

Maurice N, Thierry AM, Glowinski J, Deniau JM (2003) Spontaneous and evoked activity of substantia nigra pars reticulata neurons during high-frequency stimulation of the subthalamic nucleus. $J$ Neurosci 23:9929-9936. Medline

Meissner W, Leblois A, Hansel D, Bioulac B, Gross CE, Benazzouz A, Boraud $T$ (2005) Subthalamic high frequency stimulation resets subthalamic firing and reduces abnormal oscillations. Brain 128: 2372-2382. CrossRef Medline

Mesulam MM, Mash D, Hersh L, Bothwell M, Geula C (1992) Cholinergic innervation of the human striatum, globus pallidus, subthalamic nucleus, substantia nigra, and red nucleus. J Comp Neur 323:252-268. CrossRef Medline

Nambu A, Takada M, Inase M, Tokuno H (1996) Dual somatotopical representations in the primate subthalamic nucleus: evidence for ordered but reversed body-map transformations from the primary motor cortex and the supplementary motor area. J Neurosci 16: 2671-2683. Medline

Nambu A, Tokuno H, Inase M, Takada M (1997) Corticosubthalamic input zones from forelimb representations of the dorsal and ventral divisions of the premotor cortex in the macaque monkey: comparison with the input zones from the primary motor cortex and the supplementary motor area. Neurosci Lett 239:13-16. Medline

Nambu A, Tokuno H, Hamada I, Kita H, Imanishi M, Akazawa T, Ikeuchi Y, Hasegawa N (2000) Excitatory cortical inputs to pallidal neurons via the subthalamic nucleus in the monkey. $J$ Neurophysiol 84:289-300. Medline

O'Sullivan SS, Evans AH, Lees AJ (2009) Dopamine dysregulation syndrome: an overview of its epidemiology, mechanisms and management. CNS Drugs 23:157-170.

Okun MS, Fernandez HH, Wu SS, Kirsch-Darrow L, Bowers D, Bova F, Suelter M, Jacobson CE, 4th, Wang X, Gordon CW Jr, Zeilman P, Romrell J, Martin P, Ward H, Rodriguez RL, Foote KD (2009) Cognition and mood in Parkinson's disease in subthalamic nucleus versus globus pallidus interna deep brain stimulation: the COMPARE trial. Ann Neurol 65:586-595. CrossRef

Parent A, Hazrati LN (1993) Anatomical aspects of information processing in primate basal ganglia. Trends Neurosci 16:111-116. Medline

Parent A, Hazrati LN (1995a) Functional anatomy of the basal ganglia. II. The place of subthalamic nucleus and external pallidum in basal ganglia circuitry. Brain Res Brain Res Rev 20:128-154. 
Parent A, Hazrati LN (1995b) Functional anatomy of the basal ganglia. I. The cortico-basal ganglia-thalamo-cortical loop. Brain Res Brain Res Rev 20:91-127. Medline

Parent M, Parent A (2004) The pallidofugal motor fiber system in primates. Parkinsonism Relat Disord 10:203-211. CrossRef Medline

Parent M, Wallman MJ, Gagnon D, Parent A (2011) Serotonin innervation of basal ganglia in monkeys and humans. J Chem Neuroanat 41:256-265. CrossRef Medline

Périer C, Agid Y, Hirsch EC, Féger J (2000) Ipsilateral and contralateral subthalamic activity after unilateral dopaminergic lesion. Neuroreport 11:3275-3278. Medline

Plantinga BR, Temel Y, Roebroeck A, Uludağ K, Ivanov D, Kuijf ML, Ter Haar Romenij BM (2014) Ultra-high field magnetic resonance imaging of the basal ganglia and related structures. Front Hum Neurosci 8:876CrossRef Medline

Plantinga BR, Temel Y, Duchin Y, Uludag K, Patriat R, Roebroeck A, Kuijf M, Jahanshahi A, Ter Haar Romenij B, Vitek J, Harel N (2016) Individualized parcellation of the subthalamic nucleus in patients with Parkinson's disease with 7T MRI. Neuroimage pii:S10538119(16)30486-4.

Pollo C, Vingerhoets F, Pralong E, Ghika J, Maeder P, Meuli R, Thiran JP, Villemure JG (2007) Localization of electrodes in the subthalamic nucleus on magnetic resonance imaging. J Neurosurg 106: 36-44. CrossRef Medline

Ray NJ, Jenkinson N, Wang S, Holland P, Brittain JS, Joint C, Stein JF, Aziz T (2008) Local field potential beta activity in the subthalamic nucleus of patients with Parkinson's disease is associated with improvements in bradykinesia after dopamine and deep brain stimulation. Exp Neurol 213:108-113. CrossRef Medline

Robledo P, Féger J (1990) Excitatory influence of rat subthalamic nucleus to substantia nigra pars reticulata and the pallidal complex: electrophysiological data. Brain Res 518:47-54. Medline

Rodriguez MC, Obeso JA, Olanow CW (1998) Subthalamic nucleusmediated excitotoxicity in Parkinson's disease: a target for neuroprotection. Ann Neurol 44:S175-S188. Medline

Rodriguez-Oroz MC, Obeso JA, Lang AE, Houeto JL, Pollak P, Rehncrona S, Kulisevsky J, Albanese A, Volkmann J, Hariz MI, Quinn NP, Speelman JD, Guridi J, Zamarbide I, Gironell A, Molet J, Pascual-Sedano B, Pidoux B, Bonnet AM, Agid Y, et al. (2005) Bilateral deep brain stimulation in Parkinson's disease: a multicentre study with 4 years follow-up. Brain 128:2240-2249. CrossRef Medline

Rosin B, Slovik M, Mitelman R, Rivlin-Etzion M, Haber SN, Israel Z, Vaadia E, Bergman H (2011) Closed-loop deep brain stimulation is superior in ameliorating parkinsonism. Neuron 72:370-384. CrossRef Medline

Rothlind JC, York MK, Carlson K, Luo P, Marks WJ Jr, Weaver FM, Stern M, Follett K, Reda D; CSP-468 Study Group (2015) Neuropsychological changes following deep brain stimulation surgery for Parkinson's disease: comparisons of treatment at pallidal and subthalamic targets versus best medical therapy. J Neurol Neurosurg Psychiatry 86:622-629. CrossRef

Rouaud T, Lardeux S, Panayotis N, Paleressompoulle D, Cador M, Baunez C (2010) Reducing the desire for cocaine with subthalamic nucleus deep brain stimulation. Proc Natl Acad Sci USA 107: 1196-1200. CrossRef Medline

Sadikot AF, Parent A, François C (1992) Efferent connections of the centromedian and parafascicular thalamic nuclei in the squirrel monkey: a PHA-L study of subcortical projections. J Comp Neur 315:137-159. CrossRef Medline

Shimamoto SA, Ryapolova-Webb ES, Ostrem JL, Galifianakis NB, Miller KJ, Starr PA (2013) Subthalamic nucleus neurons are synchronized to primary motor cortex local field potentials in Parkinson's disease. J Neurosci 33:7220-7233. CrossRef Medline

Shink E, Bevan MD, Bolam JP, Smith Y (1996) The subthalamic nucleus and the external pallidum: two tightly interconnected structures that control the output of the basal ganglia in the monkey. Neuroscience 73:335-357. Medline
Smith Y, Hazrati LN, Parent A (1990) Efferent projections of the subthalamic nucleus in the squirrel monkey as studied by the PHA-L anterograde tracing method. J Comp Neur 294:306-323. CrossRef

Syed EC, Benazzouz A, Taillade M, Baufreton J, Champeaux K, Falgairolle M, Bioulac B, Gross CE, Boraud T (2012) Oscillatory entrainment of subthalamic nucleus neurons and behavioural consequences in rodents and primates. Eur J Neurosci 36:3246-3257. CrossRef Medline

Tai CH, Boraud T, Bezard E, Bioulac B, Gross C, Benazzouz A (2003) Electrophysiological and metabolic evidence that high-frequency stimulation of the subthalamic nucleus bridles neuronal activity in the subthalamic nucleus and the substantia nigra reticulata. FASEB J 17:1820-1830. CrossRef Medline

Tass PA, Qin L, Hauptmann C, Dovero S, Bezard E, Boraud T, Meissner WG (2012) Coordinated reset has sustained aftereffects in Parkinsonian monkeys. Ann Neurol 72:816-820. CrossRef Medline

Temel Y, Visser-Vandewalle V, Aendekerk B, Rutten B, Tan S, Scholtissen B, Schmitz C, Blokland A, Steinbusch HW (2005) Acute and separate modulation of motor and cognitive performance in parkinsonian rats by bilateral stimulation of the subthalamic nucleus. Exp Neurol 193:43-52. CrossRef Medline

Temel Y, Blokland A, Ackermans L, Boon P, van KranenMastenbroek VH, Beuls EA, Spincemaille GH, Visser-Vandewalle V (2006a) Differential effects of subthalamic nucleus stimulation in advanced Parkinson disease on reaction time performance. Exp Brain Res 169:389-399.

Temel Y, Kessels A, Tan S, Topdag A, Boon P, Visser-Vandewalle V (2006b) Behavioural changes after bilateral subthalamic stimulation in advanced Parkinson disease: a systematic review. Parkinsonism Relat Disord 12:265-272.

Temel Y, Boothman LJ, Blokland A, Magill PJ, Steinbusch HW, Visser-Vandewalle V, Sharp T (2007) Inhibition of 5-HT neuron activity and induction of depressive-like behavior by highfrequency stimulation of the subthalamic nucleus. Proc Natl Acad Sci USA 104:17087-17092. CrossRef Medline

Tournier JD, Calamante F, Connelly A (2007) Robust determination of the fibre orientation distribution in diffusion MRI: non-negativity constrained super-resolved spherical deconvolution. Neuroimage 35:1459-1472. CrossRef Medline

Uslaner JM, Robinson TE (2006) Subthalamic nucleus lesions increase impulsive action and decrease impulsive choice - mediation by enhanced incentive motivation? Eur J Neurosci 24:23452354. CrossRef Medline

Vitek JL (2002) Mechanisms of deep brain stimulation: excitation or inhibition. Mov Disord 17 [Suppl3]:S69-S72. Medline

Weaver FM, Follett K, Stern M, Hur K, Harris C, Marks WJ Jr, Rothlind J, Sagher O, Reda D, Moy CS, Pahwa R, Burchiel K, Hogarth P, Lai EC, Duda JE, Holloway K, Samii A, Horn S, Bronstein J, Stoner G, et al. (2009) Bilateral deep brain stimulation vs best medical therapy for patients with advanced Parkinson disease: a randomized controlled trial. JAMA 301:63-73.

Wichmann T, Bergman H, DeLong MR (1994a) The primate subthalamic nucleus. I. Functional properties in intact animals. J Neurophysiol 72:494-506.

Wichmann T, Bergman H, DeLong MR (1994b) The primate subthalamic nucleus. III. Changes in motor behavior and neuronal activity in the internal pallidum induced by subthalamic inactivation in the MPTP model of parkinsonism. J Neurophysiol 72:521-530.

Windels F, Bruet N, Poupard A, Urbain N, Chouvet G, Feuerstein C, Savasta M (2000) Effects of high frequency stimulation of subthalamic nucleus on extracellular glutamate and GABA in substantia nigra and globus pallidus in the normal rat. Eur $\mathrm{J}$ Neurosci 12: 4141-4146. Medline

Windels F, Carcenac C, Poupard A, Savasta M (2005) Pallidal origin of GABA release within the substantia nigra pars reticulata during high-frequency stimulation of the subthalamic nucleus. J Neurosci 25:5079-5086. CrossRef Medline 
Wingeier B, Tcheng T, Koop MM, Hill BC, Heit G, Bronte-Stewart HM (2006) Intra-operative STN DBS attenuates the prominent beta rhythm in the STN in Parkinson's disease. Exp Neurol 197:244251. CrossRef Medline

Winstanley CA (2011) The utility of rat models of impulsivity in developing pharmacotherapies for impulse control disorders. $\mathrm{Br} \mathrm{J}$ Pharmacol 164:1301-1321. CrossRef Medline

Winstanley CA, Baunez C, Theobald DE, Robbins TW (2005) Lesions to the subthalamic nucleus decrease impulsive choice but impair autoshaping in rats: the importance of the basal ganglia in Pavlovian conditioning and impulse control. Eur J Neurosci 21:31073116. CrossRef Medline
Winter C, Mundt A, Jalali R, Joel D, Harnack D, Morgenstern R, Juckel G, Kupsch A (2008) High frequency stimulation and temporary inactivation of the subthalamic nucleus reduce quinpiroleinduced compulsive checking behavior in rats. Exp Neurol 210: 217-228. CrossRef Medline

Wu XX, Shuai JW (2012) Multistability in a neuron model with extracellular potassium dynamics. Phys Rev E Stat Nonlin Soft Matter Phys 85:061911. CrossRef Medline

Zheng F, Lammert K, Nixdorf-Bergweiler BE, Steigerwald F, Volkmann J, Alzheimer $C$ (2011) Axonal failure during high frequency stimulation of rat subthalamic nucleus. J Physiol 589:2781-2793. CrossRef Medline 